\title{
NEGARA DAN PENDIDIKAN, SENTRALISASI DAN DESENTRALISASI PENDIDIKAN, MANAJEMEN BERBASIS SEKOLAH
}

\author{
SUWARDI \\ Universitas Ekasakti \\ suwardi531@gmail.com
}

\begin{abstract}
Thus, as an impact of the centralistic education system, efforts to create education that can give birth to human figures who have freedom of thought, are able to solve problems independently, work and live in creative groups full of initiative and desire, have adequate interpersonal skills as a provision for society. it becomes very difficult to realize. Centralization was widely used by the government before regional autonomy. The weakness of the centralized system is where a local government policy and decision is produced by people who are in the central government so that the time to decide on something is longer. Indonesia as a developing country with various socio-cultural characteristics in common, also follows a centralized system that has long been developed in developing countries. Thus, as an impact of the centralized education system, efforts to create education that can give birth to human figures who have freedom of thought, are able to solve problems independently, work and live in creative groups full of initiative and passion, have adequate interpersonal skills as a provision for society to become very difficult to materialize. As a consequence, the implementation of education in Indonesia is completely uniform, decisions from above, such as a uniform curriculum regardless of the level of relevance to children's lives and their environment. As a consequence, the position and role of students tend to be used as objects so that those who have the opportunity to develop their creativity and interests are in accordance with their talents. The term school-based management is a translation of school-based management. This term first appeared in the United States when people began to question the relevance of education to the demands and development of local communities. SBM is a new paradigm in the world of education, which provides broad autonomy at the school level (community involvement) in the framework of national education policies. Autonomy is given so that schools can freely manage resources and financial resources by allocating them according to priority needs, and are more responsive to local needs.
\end{abstract}

Keywords: Education, Centralization, Decentralization, School Based.

Abstrak: Dengan demikian, sebagai dampak sistem pendidikan sentralistik, maka upaya mewujudkan pendidikan yang dapat melahirkan sosok manusia yang memiliki kebebasan berpikir, mampu memecahkan masalah secara mandiri, bekerja dan hidup dalam kelompok kreatif penuh inisiatif dan impati, memiliki keterampilan interpersonal yang memadai sebagai bekal masyarakat menjadi sangat sulit untuk di wujudkan.Sentralisasi banyak digunakan pemerintah sebelum otonomi daerah. Kelemahan sistem sentralisasi adalah dimana sebuah kebijakan dan keputusan pemerintah daerah dihasilkan oleh orang-orang yang berada di pemerintah pusat sehingga waktu untuk memutuskan suatu hal menjadi lebih lama. Indonesia sebagai negara berkembang dengan berbagai kesamaan ciri sosial budayanya, juga mengikuti sistem sentralistik yang telah lama dikembangkan pada negara berkembang. Dengan demikian, sebagai dampak sistem pendidikan sentralistik, maka upaya mewujudkan pendidikan yang dapat melahirkan sosok manusia yang memiliki kebebasan berpikir, 
mampu memecahkan masalah secara mandiri, bekerja dan hidup dalam kelompok kreatif penuh inisiatif dan impati, memiliki keterampilan interpersonal yang memadai sebagai bekal masyarakat menjadi sangat sulit untuk di wujudkan. Konsekuensinya penyelenggaraan pendidikan di Indonesia serba seragam, serba keputusan dari atas, seperti kurikulum yang seragam tanpa melihat tingkat relevansinya bagi kehidupan anak dan lingkungannya. Konsekuensinya, posisi dan peran siswa cenderung dijadikan sebagai objek agar yang memiliki peluang untuk mengembangkan kreatifitas dan minatnya sesuai dengan talenta yang dimilikinya. Istilah manajemen berbasis sekolah merupakan terjemahan dari school-based management. Istilah ini pertama kali muncul di Amerika Serikat ketika masyarakat mulai mempertanyakan relevansi pendidikan dengan tuntutan dan perkembangan masyarakat setempat. MBS merupakan paradigma baru dalam dunia pendidikan, yang memberikan otonomi luas pada tingkat sekolah (pelibatan masyarakat) dalam kerangka kebijakan pendidikan nasional. Otonomi diberikan agar sekolah leluasa mengelola sumber daya dan sumber dana dengan mengalokasikannya sesuai dengan prioritas kebutuhan, serta lebih tanggap dengan kebutuhan setempat.

Kata Kunci: Pendidikan, Sentralisasi, Desentralisasi, Berbasis Sekolah.

\section{A. Pendahuluan}

Sebagai sebuah negara Indonesia tentu memiliki prinsip dasar dan berbagai aturan untuk warganya. Sehingga semua warga bisa hidup bersama-sama dalam sebuah negara hingga turun temurun. Dilihat dari pengertiannya, negara sendiri adalah suatu organisasi atau lembaga tertinggi dari kelompok masyarakat yang terdiri dari sekumpulan orang di wilayah tertentu, memiliki cita-cita untuk hidup bersama, serta memiliki sistem pemerintahan yang berdaulat (British Council, 2000). Dalam penyelenggaraan negara terdapat tiga sifat, yakni (Nurkholis, 2001): 1) Bersifat memaksa, yaitu memaksa masyarakatnya untuk melakukan peraturan yang telah ditetapkan; 2) Bersifat monopoli, yaitu menguasai semua sumber daya alam yang penting di dalam wilayah negara tersebut; dan 3) Bersifat totalitas, negara memiliki wewenang atas semua hal tanpa pengecualian.

Sebuah negara harus memiliki beberapa unsur agar bisa disebut sebagai negara. Sehingga sebuah wilayah yang telah memenuhi syarat, bisa dijadikan negara atas kesepakatan rakyatnya juga negara lain. Setiap unsur di dalam negara akan saling melengkapi, sehingga tanpa adanya salah satu unsur maka suatu negara tidak akan sempurna. Syarat berdirinya sebuah negara ialah sebagai berikut: a) Adanya Wilayah Wilayah merupakan suatu daerah yang dikuasai dan ditempati oleh sekelompok manusia, serta menjadi batas teritorial suatu kedaulatan. Wilayah ini meliputi tiga bagian, yaitu darat, laut, dan udara; b) Ada Penduduk/ Rakyat Penduduk atau rakyat adalah orang-orang yang menetap pada suatu tempat dalam periode waktu yang cukup lama. Rakyat merupakan unsur terpenting dalam suatu negara, dan negara hanya dapat terbentuk bila ada kesepakatan para penduduknya; c) Ada Pemerintahan yang Berdaulat Pemerintah adalah suatu lembaga di dalam negara yang memegang kekuasaan tertinggi dan dibentuk untuk melaksanakan jalannya pemerintahan suatu negara; d) Terdapat Pengakuan dari Negara Lain Suatu negara belum sempurna bila belum ada pengakuan dari negara lainnya. Pengakuan ini diperlukan guna mencegah terjadinya ancaman dari dalam (kudeta) atau campur tangan dari negara lain. Adanya pengakuan dari negara-negara lain akan membantu suatu negara untuk menjalin hubungan kerjasama dengan negara lain di berbagai bidang (ekonomi, politik, sosial budaya, pertahanan dan keamanan). 
Pada dasarnya fungsi negara adalah sebagai lembaga yang mewujudkan cita-cita dan harapan masyarakat di negara tersebut. Mengacu pada pengertian negara di atas, berikut ini adalah beberapa fungsi negara: a) Fungsi Ketertiban dan Keamanan Negara mengatur serta melaksanakan ketertiban dan keamanan dalam kehidupan bermasyarakat. Dengan begitu maka kegiatan para warga negara dapat berlangsung dengan baik; b) Fungsi Kesejahteraan dan Kemakmuran Negara mengupayakan kesejahteraan dan kemakmuran warga negara, khususnya di bidang ekonomi dan sosial; c) Fungsi Pertahanan Negara mempertahankan dan menjamin kelangsungan hidup suatu bangsa dari berbagai ancaman, baik serangan dari dalam (kudeta) maupun serangan dari luar (invasi); dan d) Fungsi Penegakan Keadilan Negara harus dapat menjamin keadilan sosial bagi seluruh warganya yang mencakup seluruh aspek kehidupan (ideologi, ekonomi, sosial budaya, politik, pertahanan dan keamanan). Fungsi keadilan ini dilakukan dengan cara penegakan hukum melalui badan-badan peradilan di suatu negara.

Pendidikan adalah kebutuhan pokok setiap individu. Oleh karena begitu pentingnya pendidikan, pemerintah mewajibkan pendidikan setidaknya selama 9 tahun dan disarankan lebih dari itu. Sekilas, kita bisa membedakan bagaimana cara bersikap dan cara berpikir antara mereka yang berpendidikan dan yang tidak tuntas dari segi pendidikannya. Pada kesempatan kali ini, kita akan membahas pengertian pendidikan, apa saja tujuan pendidikan, apa saja fungsinya dan termasuk juga jenis pendidikan yang ada. Secara umum, yang dimaksud dengan pendidikan adalah mengikuti kegiatan proses pembelajaran untuk memperoleh pengetahuan dan keterampilan. Peserta didik sekaligus mengikuti kebiasaan dari sekumpulan besar manusia dari satu generasi ke generasi yang lain dengan melalui proses pengajaran oleh guru, pelatihan dan juga penelitian.

Adapun definisi lain dari pendidikan adalah usaha yang disengaja dan dilakukan secara sistematis agar suasana belajar kondusif sehingga para peserta didik bisa mengembangkan bakat dan kemampuan dirinya dengan lebih maksimal lagi. Dengan mengikuti pendidikan yang sudah ditempuh, harapannya para peserta didik mampu memiliki akhlak yang mulia, berkepribadian luhur, tinggi kemampuan spiritualitasnya, memiliki kecerdasan yang luar biasa dan juga mempunyai keterampilan yang nantinya berguna bagi dirinya sendiri dan juga bagi masyarakat sekitar (H.A.R. Tilaar, 1999). Singkatnya, definisi pendidikan merupakan proses pembelajaran yang dilakukan kepada peserta didik supaya yang bersangkutan memiliki pengertian dan pemahaman yang baik mengenai sesuatu dan nantinya tumbuh menjadi pribadi yang gemar berpikir kritis dan menjadi lebih baik lagi, baik itu dari segi afektif, kognitif maupun psikomotoriknya (Oemar Hamalik, 1991). Definisi pendidikan sesungguhnya relatif, sebab setiap orang memiliki pengertian subjektif tentang pendidikan berdasarkan sudut pandang dan luas wawasan yang dimilikinya. Untuk lebih mengenal makna pendidikan, berikut ini adalah beberapa pengertian pendidikan berdasarkan pendapat paha ahli, penulis buku, cendikiawan dan tokoh dunia yang memiliki peranan khusus di dunia pendidikan.

\section{B. Metodologi Penelitian}

Metodologi penelitian ini memakai penelitian naratif. Penelitian naratif dapat dianggap sebagai metode penelitian itu sendiri tetapi juga dapat dianggap fenomena yang diteliti. Metode naratif dapat dianggap sebagai "ukuran dunia nyata" yang sesuai ketika "masalah kehidupan nyata" diselidiki. Dalam pendekatan linier dasar, mereka 
mencakup studi tentang pengalaman seorang individu yang merangkul kisah-kisah kehidupan dan mengeksplorasi signifikansi yang dipelajari dari pengalaman individu tersebut. Namun, dalam kebanyakan kasus seseorang akan menciptakan kumpulan narasi yang masing-masing bertumpu pada yang lain. Penelitian naratif ditetapkan oleh validasi audiens. Ini adalah bagian yang berguna dari penyelidikan ilmu sosial, tetapi mungkin tidak selalu berdiri sendiri untuk bukti dan dukungan dalam penarikan kesimpulan laporan. Timbul pertanyaan tentang keakuratan cerita yang dilihat secara objektif meskipun harus dilihat dalam konteks sosial budaya. Narasi memberikan pandangan individu untuk diakses berdasarkan kemampuannya. Validasi semacam itu dimungkinkan dengan menguatkan dari wacana lain yang mulai naratif. Penekanannya adalah pada pengalaman bertingkat.

\section{Hasil dan Pembahasan}

\section{Sentralisasi Dan Desentralisasi Pendidikan}

Sentralsasi adalah seluruh wewenang terpusat pada pemerintah pusat. Daerah tinggal menunggu instruksi dari pusat untuk melaksanakan kebijakan-kebijakan yang telah digariskan menurut Undang-Undang. Menurut ekonomi manajemen sentralisasi adalah memusatkan semua wewenang kepada sejumlah kecil manager atau yang berada di suatu puncak pada sebuah struktur organisasi. Sentralisasi banyak digunakan pemerintah sebelum otonomi daerah. Kelemahan sistem sentralisasi adalah dimana sebuah kebijakan dan keputusan pemerintah daerah dihasilkan oleh orang-orang yang berada di pemerintah pusat sehingga waktu untuk memutuskan suatu hal menjadi lebih lama. Indonesia sebagai negara berkembang dengan berbagai kesamaan ciri sosial budayanya, juga mengikuti sistem sentralistik yang telah lama dikembangkan pada negara berkembang. Konsekuensinya penyelenggaraan pendidikan di Indonesia serba seragam, serba keputusan dari atas, seperti kurikulum yang seragam tanpa melihat tingkat relevansinya bagi kehidupan anak dan lingkungannya (Fasli Jalal dan Dedi Supriadi, 2001).

Konsekuensinya, posisi dan peran siswa cenderung dijadikan sebagai objek agar yang memiliki peluang untuk mengembangkan kreatifitas dan minatnya sesuai dengan talenta yang dimilikinya. Dengan adanya sentralisasi pendidikan telah melahirkan berbagai fenomena yang memperhatikan seperti: 1) Totaliterisme penyelenggaraan pendidikan; 2) Keseragaman manajemen, sejak dalam aspek perencanaan, pengelolaan, evaluasi, hingga model pengembangan sekolah dan pembelajaran; 3) Keseragaman pola pembudayaan masyarakat; 4) Melemahnya kebudayaan daerah dan 5) Kualitas manusia yang robotic, tanpa inisiatif dan kreatifitas (Umaedi, 2000). Dengan demikian, sebagai dampak sistem pendidikan sentralistik, maka upaya mewujudkan pendidikan yang dapat melahirkan sosok manusia yang memiliki kebebasan berpikir, mampu memecahkan masalah secara mandiri, bekerja dan hidup dalam kelompok kreatif penuh inisiatif dan impati, memiliki keterampilan interpersonal yang memadai sebagai bekal masyarakat menjadi sangat sulit untuk di wujudkan.

Desentralisasi di Indonesia sudah ada cukup lama, dimulai sejak tahun 1973, yaitu sejak diterbitkannya UU no. 5 tahun 1973 tentang pokok-pokok pemerintahan daerah otonomi dan pokok-pokok penyelenggaraan pemerintahan yang menjadi tugas pusat dan daerah. Dan terdapat pula pada PP No. 45 tahun 1992 dan dikuatkan lagi melalui PP No. 8 tahun 1995. Menurut UU No.22 Tahun 1999 tentang pemerintahan daerah, desentralisasi dikonsepsikan sebagai penyerahan wewenang yang disertai tanggung jawab pemerintah oleh pemerintah pusat kepada daerah otonom. Beberapa alasan yang mendasari perlunya desentralisasi: 1) Mendorong terjadinya partisipasi 
dari bawah secara lebih luas; 2) Mengakomodasi terwujudnya prinsip demokrasi; 3) Mengurangi biaya akibat alur birokrasi yang panjang sehingga dapat meningkatkan efisiensi; 4) Memberi peluang untuk memanfaatkan potensi daerah secara optimal; 5) Mengakomodasi kepentingan politik; dan 6) Mendorong peningkatan kualitas produk yang lebih kompetitif.

Desentralisasi Community Based Education mengisyaratkan terjadinya perubahan kewenangan dalam pemerintah antara lain: 1) Perubahan berkaitan dengan urusan yang tidak diatur oleh pemerintah pusat, secara otomatis menjadi tanggung jawab pemerintah daerah, termasuk dalam pengelolaan pendidikan; dan 2) Perubahan berkenaan dengan desentralisasi pengelolaan pendidikan, dalam hal ini pelempahan wewenang dalam pengelolaan pendidikan dari pemerintah pusat ke daerah otonom, yang menempatkan kabupaten/kota sebagai sentra desentralisasi. Desentralisasi adalah pendelegasian wewenang dalam membuat keputusan dan kebijakan kepada orangorang pada level bawah ( daerah ). Pada sistem pendidikan yang terbaru tidak lagi menerapkan sistem pendidikan sentralisasi, melainkan sistem otonomi daerah atau otda yang memberikan wewenang kepada pemerintah daerah untuk mengambil kebijakan yang tadinya diputuskan seluruhnya oleh pemerintah pusat.

Dari beberapa pengalaman di negara lain, kegagalan desentralisasi di akibatkan oleh beberapa hal: 1) Masa transisi dari sistem sentralisasi ke desentralisasi memungkinkan terjadinya perubahan secara gradual dan tidak memadai serta jadwal pelaksanaan yang tergesa-gesa; 2) Kurang jelasnya pembatasan rinci kewenangan antara pemerintah pusat, propinsi dan daerah; 3) Kemampuan keuangan daerah yang terbatas; 4) Sumber daya manusia yang belum memadai; 5) Kapasitas manajemen daerah yang belum memadai; 6) Restrukturisasi kelembagaan daerah yang belum matang; dan 7) Pemerintah pusat secara psikologis kurang siap untuk kehilangan otoritasnya. Selain dampak negatif tentu saja desentralisasi pendidikan juga telah membuktikan keberhasilannya antara lain: 1) Mampu memenuhi tujuan politis, yaitu melaksanakan demokratisasi dalam pengelolaan pendidikan; 2) Mampu membangun partisipasi masyarakat sehingga melahirkan pendidikan yang relevan, karena pendidikan benar-benar dari oleh dan untuk masyarakat; dan 3) Mampu menyelenggarakan pendidikan dengan memfasilitasi proses belajar mengajar yang kondusif, yang pada gilirannya akan meningkatkan kualitas belajar siswa.

\section{Manajemen Berbasis Sekolah}

Istilah manajemen berbasis sekolah merupakan terjemahan dari school-based management. Istilah ini pertama kali muncul di Amerika Serikat ketika masyarakat mulai mempertanyakan relevansi pendidikan dengan tuntutan dan perkembangan masyarakat setempat. MBS merupakan paradigma baru dalam dunia pendidikan, yang memberikan otonomi luas pada tingkat sekolah (pelibatan masyarakat) dalam kerangka kebijakan pendidikan nasional. Otonomi diberikan agar sekolah leluasa mengelola sumber daya dan sumber dana dengan mengalokasikannya sesuai dengan prioritas kebutuhan, serta lebih tanggap dengan kebutuhan setempat. Kewenangan yang bertumpu pada sekolah merupakan inti dari MBS yang dipandang memiliki tingkat efektivitas tinggi serta memberikan beberapa keuntungan sebagai berikut: 1) Kebijakan dan kewenangan sekolah membawa pengaruh langsung kepada peserta didik, orang tua dan guru; 2) Bertujuan bagaimana memanfaatkan sumber daya lokal; 3) Efektif dalam melakukan pembinaan peserta didik seperti kehadiran, hasil belajar, tingkat pengulangan, tingkat putus sekolah, moral guru, dan iklim sekolah; dan 4) Adanya 
perhatian bersama untuk mengambil keputusan, memberdayakan guru, manajemen sekolah, rancang ulang sekolah, dan perubahan perencanaan.

MBS yang ditandai dengan otonomi sekolah dan pelibatan masyarakat merupakan respon pemerintah terhadap gejala-gejala yang muncul di masyarakat, bertujuan untuk meningkatkan efisiensi, mutu dan pemerataan pendidikan. Peningkatan efisiensi antara lain diperoleh melalui keleluasaan mengelola sumber daya partisipasi masyarakat dan penyederhanaan birokrasi. Sementara peningkatan mutu dapat diperoleh antara lain melalui partisipasi orang tua terhadap sekolah, fleksibilitas pengelolaan sekolah dan kelas, peningkatan profesionalisme guru dan kepala sekolah, berlakunya sistem insentif dan disinsentif. Peningkatan pemerataan antara lain diperoleh melalui peningkatan partisipasi masyarakat yang memungkinkan pemerintah lebih berkonsentrasi pada kelompok tertentu. MBS memberikan kebebasan dan kekuasaan yang besar pada sekolah, disertai seperangkat tanggung jawab. Dengan adanya otonomi yang memberikan tanggung jawab pengelolaan sumber daya dan pengembangan strategis MBS sesuai dengan kondisi setempat, sekolah dapat lebih meningkatkan kesejahteraan guru sehingga dapat lebih berkonsentrasi pada tugas. Selain itu, MBS mendorong profesionalisme guru dan kepala sekolah sebagai pemimpin pendidikan di sekolah (MM Wahyuningrum, 2006).

Menurut Usman (2009:624), prinsip-prinsip yang perlu diperhatikan dalam melaksanakan MBS antara lain: 1) Komitmen, kepala sekolah dan warga sekolah harus mempunyai komitmen yang kuat dalam upaya menggerakkan semua warga sekolah untuk ber-MBS; 2) Kesiapan, semua warga sekolah harus siap fisik dan mental untuk ber-MBS; 3) Keterlibatan, pendidikan yang efektif melibatkan semua pihak dalam mendidik anak; 4) Kelembagaan, sekolah sebagai lembaga adalah unit terpenting bagi pendidikan yang efektif; 5) Keputusan, segala keputusan sekolah dibuat oleh pihak yang mengerti tentang pendidikan; 6) Kesadaran, guru-guru harus memiliki kesadaran untuk membantu dalam pembuatan keputusan program pendidikan dan kurikulum; 7) Kemandirian, sekolah harus diberi otonomi sehingga memiliki kemandirian dalam membuat keputusan pengalokasian dana; dan 8) Ketahanan, perubahan akan bertahan lebih lama apabila melibatkan stake holder sekolah. Menurut Usman (2009:629), indikator bahwa MBS sudah berhasil di sekolah ditunjukkan oleh beberapa hal: 1) Adanya kemandirian sekolah yang kuat; 2) Adanya kemitraan sekolah yang efektif; 3) Adanya partisipasi yang kuat dari masyarakat; 4) Adanya keterbukaan yang bertanggung jawab dan meluas dari pihak sekolah dan masyarakat; dan 5) Adanya akuntabilitas yang dapat dipertanggungjawabkan oleh sekolah.

\section{Daftar Pustaka}

Sentralisasi adalah seluruh wewenang terpusat pada pemerintah pusat. Daerah tinggal menunggu instruksi dari pusat untuk melaksanakan kebijakan-kebijakan yang telah digariskan menurut Undang-Undang. Menurut ekonomi manajemen sentralisasi adalah memusatkan semua wewenang kepada sejumlah kecil manager atau yang berada di suatu puncak pada sebuah struktur organisasi. Sentralisasi banyak digunakan pemerintah sebelum otonomi daerah. Kelemahan sistem sentralisasi adalah dimana sebuah kebijakan dan keputusan pemerintah daerah dihasilkan oleh orang-orang yang berada di pemerintah pusat sehingga waktu untuk memutuskan suatu hal menjadi lebih lama. Indonesia sebagai negara berkembang dengan berbagai kesamaan ciri sosial budayanya, juga mengikuti sistem sentralistik yang telah lama dikembangkan pada negara berkembang. Konsekuensinya penyelenggaraan pendidikan di Indonesia serba seragam, serba keputusan dari atas, seperti kurikulum yang seragam tanpa melihat 
tingkat relevansinya bagi kehidupan anak dan lingkungannya. Konsekuensinya, posisi dan peran siswa cenderung dijadikan sebagai objek agar yang memiliki peluang untuk mengembangkan kreatifitas dan minatnya sesuai dengan talenta yang dimilikinya. Istilah manajemen berbasis sekolah merupakan terjemahan dari school-based management. Istilah ini pertama kali muncul di Amerika Serikat ketika masyarakat mulai mempertanyakan relevansi pendidikan dengan tuntutan dan perkembangan masyarakat setempat. MBS merupakan paradigma baru dalam dunia pendidikan, yang memberikan otonomi luas pada tingkat sekolah (pelibatan masyarakat) dalam kerangka kebijakan pendidikan nasional. Otonomi diberikan agar sekolah leluasa mengelola sumber daya dan sumber dana dengan mengalokasikannya sesuai dengan prioritas kebutuhan, serta lebih tanggap dengan kebutuhan setempat.

\section{Daftar Pustaka}

British Council (2000), "Pengenalan Proyek DSSD”. makalah pada Lokakarya ST 1. Driyarkara, Driyarkara Tentang Pendidikan, Yayasan Kanisius, Yogyakarta, 1980.

Fasli Jalal dan Dedi Supriadi (2001), Reformasi Pendidikan Dalam Konteks Otonomi Daerah, Yogyakarta: Adicita.

H.A.R. Tilaar (1999), Manajemen Pendidikan Nasional, Bandung: Remaja Rosdakarya.

MM Wahyuningrum, (2006), Penerapan Manajemen Berbasis Sekolah Dan Desentralisasi Pendidikan Pada Era Otonomi Daerah, Jurnal Manajemen Pendidikan, Volume 2, Nomor 2.

Nurkholis (2001), Hakikat Desentralisasi Model Manajemen Berbasis Sekolah, Jakarta.

Oemar Hamalik (1991), Perencanaan dan Manajemen Pendidikan, Bandung: Mundar Maju.

Umaedi (2000), Manajemen Peningkatan Mutu Berbasis Sekolah (Sebuah pendekatan baru dalam pengelolaan sekolah untuk peningkatan mutu), Dinamika Pendidikan No.1/tahun VII, Yogyakarta, FIP - UNY

Usman, Husaini. 2009. Manajemen: Teori Praktik, dan Riset Pendidikan Edisi 3. Jakarta: Bumi Aksara.

Mulyasa, E. 2002. Manajemen Berbasis Sekolah: Konsep, Strategi dan Implementasi. Bandung: Remaja Rosdakarya. 